\title{
A study on the antioxidant and antimicrobial activities in the chloroformic and methanolic extracts of 6 important medicinal plants collected from North of Iran
}

\author{
Zahra Hadadi ${ }^{1}$, Ghorban Ali Nematzadeh ${ }^{2 *}$ and Somayeh Ghahari ${ }^{2}$
}

\begin{abstract}
Background: As possible sources of natural bioactive molecules, the plant essential oils and extracts have been used globally in new antimicrobial compounds, food preservatives, and alternatives to treat infectious disease.

Methods: In this research, the antimicrobial activities of chloroformic and methanolic extracts of Sophora flavescens, Rhaponticum repens, Alhagi maurorum, Melia azedarach, Peganum harmala, and Juncus conglomeratus were evaluated against 8 bacteria (S. aureus, B. subtilis, R. toxicus, P. aeruginosa, E. coli, P. syringae, X. campestris, P. viridiflava) and 3 fungi (Pyricularia oryzae, Fusarium oxysporum and Botrytis cinerea), through disc diffusion method. Furthermore, the essential oils of plants with the highest antibacterial activity were analyzed utilizing GC/MS. Moreover, the tested plants were exposed to screening for possible antioxidant effect utilizing DPPH test, guaiacol peroxidas, and catalase enzymes. Besides, the amount of total phenol and flavonoid of these plants was measured.

Results: Among the tested plants, methanolic and chloroformic extracts of $P$. harmala fruits showed the highest antibacterial activity against the tested bacteria. Besides, the investigation of free radical scavenging effects of the tested plants indicated the highest DPPH, protein, guaiacol peroxidase, and catalase in P. harmala, M. azedarach, J. conglomeratus fruits, and J. conglomeratus fruits, respectively. In addition, the phytochemical analysis demonstrated the greatest amounts of total phenolic and flavonoid compositions in J. conglomeratus and P. harmala, respectively.
\end{abstract}

Conclusion: The results indicated that these plants could act as a promising antimicrobial agent, due to their short killing time.

Keywords: Antibacterial activities, Antifungal effects, Antioxidant activities, Plant extracts

\section{Introduction}

The plant essential oils and extracts, considered as possible sources of natural bioactive molecules, have been utilized globally in new antimicrobial compounds, food preservatives, and alternatives to treat infectious disease [1]. There are many researches about the antibacterial

\footnotetext{
*Correspondence: gh.nematzadeh@gmail.com; gh.nematzadeh@sanru.ac.ir 2 Sari University of Agricultural Sciences and Natural Resources, Genetics and Agricultural Biotechnology Institute of Tabarestan (GABIT), Sari, Iran Full list of author information is available at the end of the article
}

and antifungal activities of plant extracts and essential oils [2-6]. For example, Srinivasan et al. [7] measured the antimicrobial activity of 50 medicinal plants including Eucalyptus globulus. The results showed that Eucalyptus globulus had antimicrobial activity versus Chromobacterium, Escherichia coli, Klebsiella pneumonia, Enterobacter faecalis, Pseudomonas aeruginosa, Proteus mirabilis, Salmonella partyphy, S. typhi, Bacillus subtilis, and Staphylococcus aureus bacteria and did not show any antifungal activity on the tested fungus. Nagata et al. [8] investigated the antimicrobial activity 
of macrocarpals, phloroglucinol derivatives contained in Eucalyptus leaves, versus a diversity of bacteria containing oral bacteria. Among the tested bacteria, P. gingivalis presented the maximum sensitivity to macrocarpals. Furthermore, its trypsin-like proteinase activity and binding to saliva-coated hydroxyapatite beads were inhibited by macrocarpals. Hayet et al. [9] evaluated the antibacterial activities of ethyl acetate, chloroform, butanol and methanol extracts of peganum harmala leaves against some pathogens containing 11 g-positive and 6 g-negative bacteria, among which methanol and chloroform extracts exhibited a higher antibacterial activity versus gram-positive than gram-negative bacteria. Han and Guo [10] investigated the antibacterial activity of Angelica sinensis extract (AE), Sophora flavescens extract (SE), and herb pair A. sinensis and S. flavescens extract (HPE), according to the result of which HPE had strong antibacterial activity on Escherichia coli, Staphylococcus aureus, Shigella castellani, and Chalmers. Besides, SE was moderately active to E. coli. Moreover, Sen and Batra [11] examined the antimicrobial activity of ethanol, methanol, petroleum ether and water extracts of Melia azedarach L. leaves versus 8 human pathogens including Staphylococcus aureus, Bacillus cereus, Pseudomonas aeruginosa, Escherichia coli, Aspergillus flavus, Aspergillus niger, Fusarium oxisporum, and Rhizopus stolonifera. All the extracts indicated considerable activity versus all pathogens; however, the alcoholic extract exhibited the maximum inhibitory concentration versus all the microorganisms. Ahmad et al. [12] studied the antibacterial effect of Alhagi maurorum leaves extract and showed that the crude extract, chloroform, and ethyl acetate fractions had prominent effects, giving over $80 \%$ inhibition versus Bacillus anthrax. The crude extract displayed $80 \%$ inhibition versus Shigella dysenteriae. Similarly, the ethyl acetate and crude extract acted well versus Salmonella typhe by $78.35 \%$ and $76.50 \%$ inhibition respectively.

Furthermore, antioxidants helped to prevent cancer or heart diseases, as they could act as scavengers of free radicals and neutralized the damaging reactive free radicals in body cells before they could cause protein and lipid oxidation and decrease potential mutation [13]. Generally, plants include considerable extents of phytochemical antioxidants such as flavonoids, phenolics, carotenoids, and tannins, which can be utilized to scavenge the extra free radicals existing in the body [14]. Many researches have reported the antioxidant effect of essential oils and plant extracts. For example, Hayet et al. [9] examined the antioxidant activity of ethyl acetate, chloroform, butanol and methanol extracts of Peganum harmala leaves, demonstrating that methanol extract had the highest antioxidant activity. Nesrin and Tolan [15] proved the antioxidant effect of Hyssopus officinalis; however, it was lower than butylated hydroxytoluene and ascorbic acid. Ahmad et al. [12] indicated that extracts/fractions from Alhagi maurorum leaves displayed powerful radical scavenging activity, probably because of the existence of phenolic compounds in the plant.

The main aim of the present work was to study the chemical composition, antioxidant effects, and antimicrobial activities, while doing the phytochemical analysis of some important medicinal plants.

\section{Materials and methods \\ Plant materials}

The plants studied in this research are displayed in Table 1. All plants were collected from the research field of Sari Agricultural and Natural Resources University (SANRU), located at 53 $04^{\prime} \mathrm{E}$ and $36^{\circ} 39^{\prime} \mathrm{N}$ (Iran), and identified from flora resources. A botanist authenticated the samples (different parts of the mentioned plants) and the voucher specimen deposited in the laboratory (Table 1).

\section{Plant extracts preparation}

The collection of plant materials complied with institutional guidelines, and whole plant materials were wild type requiring no licenses for the application. The fresh selected parts of each plant were washed by the distilled water, shade-dried and then powdered in a mechanical mill. Afterward, $10 \mathrm{~g}$ of powdered materials was soaked into $170 \mathrm{~mL}$ methanol and chloroform, separately. The

Table 1 Characteristics, DPPH radical scavenging activity, Total phenol and flavonoid content of the investigated plants

\begin{tabular}{|c|c|c|c|c|c|c|}
\hline Scientific name & Family & Parts of sample & Voucher specimen no. & $\mathrm{IC}_{50}\left(\mu \mathrm{g} \mathrm{mL}^{-1}\right)$ & Total phenol content & Total flavonoid content \\
\hline S. flavescens & Fabaceae & Aerial & $966,510,282$ & $6.12 \pm 0.77$ & $39.07 \pm 0.01$ & $69.39 \pm 0.01$ \\
\hline R. repens & Asteraceae & Aerial & $966,510,574$ & $6.94 \pm 1.12$ & $24.72 \pm 0.03$ & $68.86 \pm 0.03$ \\
\hline A. maurorum & Fabaceae & Aerial & $966,510,515$ & $7.87 \pm 1.09$ & $45.43 \pm 0.02$ & $146.71 \pm 0.02$ \\
\hline M. azedarach & Meliaceae & Fruit & $966,510,063$ & $11.02 \pm 1.36$ & $21.96 \pm 0.00$ & $48.68 \pm 0.00$ \\
\hline P. harmala & Nitrariaceae & Fruit & $966,510,482$ & $0.46 \pm 0.12$ & $39.30 \pm 0.20$ & $155.29 \pm 0.20$ \\
\hline J. conglomeratus & Juncaceae & Fruit & $966,510,126$ & $7.19 \pm 0.89$ & $45.66 \pm 0.10$ & $46.54 \pm 0.10$ \\
\hline
\end{tabular}


plugged flasks of samples solution were placed at room temperature for $48 \mathrm{~h}$ by persistent shaking. The crude solutions were filtered through glass funnel and then dried via a rotary vacuum evaporator at $40{ }^{\circ} \mathrm{C}$ temperature. Finally, the extracts were filter sterilized by a $0.22 \mu \mathrm{m}$ Ministart (Sartorius) and stored at $4{ }^{\circ} \mathrm{C}$ before utilization [16].

\section{Essential oils separation}

The powdered samples (75 g) were exposed to hydrodistillation for $4 \mathrm{~h}$, using a Clevenger-type apparatus. The essential oils were dehydrated by sodium sulfate anhydrous and stored at $4{ }^{\circ} \mathrm{C}$ before GC/MS analysis [17-19].

\section{Gas chromatography coupled to mass spectrometry (GC/ MS) analysis}

GC/MS analysis was performed on an Agilent Technologies 7890A (GC) coupled with Agilent Technologies $5975 \mathrm{C}$, equipped with a fused silica capillary HP-5MS column $(30 \mathrm{~m} \times 0.25 \mathrm{~mm}$ iD, film thickness $0.25 \mu \mathrm{m})$. The oven temperature was increased from 50 to $220{ }^{\circ} \mathrm{C}$ at a speed of $15{ }^{\circ} \mathrm{C} \mathrm{min}{ }^{-1}$, retained at $220{ }^{\circ} \mathrm{C}$ for $7 \mathrm{~min}$; and then incremented to $260{ }^{\circ} \mathrm{C}$ at a speed of $15{ }^{\circ} \mathrm{C} \mathrm{min}-1$. Transfer line temperature was $250{ }^{\circ} \mathrm{C}$. Helium was used as the carrier gas, at a flow speed of $1 \mathrm{~mL} \mathrm{~min}{ }^{-1}$. The inlet temperature was $280^{\circ} \mathrm{C}$.

\section{Antioxidant assays}

Dry samples $(0.5 \mathrm{~g})$ were homogenized in the extraction buffer $(1 \mathrm{~mL})$ containing; EDTA $(1 \mathrm{mM})$, PVP $(1 \%)$ and sodium phosphate buffer $(50 \mathrm{mM}, \mathrm{pH}=7)$ by mortar and pestle. Afterwards, the homogenates were centrifuged (Eppendorf centrifuge 5430R) at 10,000 g for $15 \mathrm{~min}$. Finally, the supernatant fractions were utilized for the measurement of protein content and enzyme activities [20].

\section{Measurement of catalase (CAT)}

Catalase was examined via evaluating the primary rate of disappearance of $\mathrm{H}_{2} \mathrm{O}_{2}$, according to the Chance and Meahly [21] method. The reaction mixture, including phosphate buffer $(2.5 \mathrm{~mL}, 50 \mathrm{mM}, \mathrm{pH}=7), \mathrm{H}_{2} \mathrm{O}_{2}(0.1 \mathrm{~mL}$, $1 \%)$ and enzyme extracts $(50 \mu \mathrm{L})$, was diluted in order to keep the measurements within the linear range of the analysis. The absorbance of the reaction mixtures was recorded at $240 \mathrm{~nm}$ via spectrophotometer (Biochrom WPA Biowave II UV/Visible), in which the reduction in the absorbance at $240 \mathrm{~nm}$ was because of the reduction of $\mathrm{H}_{2} \mathrm{O}_{2}$. The activity was stated as $\mu$ mole activity $\mathrm{mg}^{-1}$ protein.

\section{Measurement of guaiacol peroxidase}

Guaiacol peroxidase (GPX) activity was studied according to the Upadhyaya et al. [22] method. The reaction combination included phosphate buffer $(2.5 \mathrm{~mL}, 50 \mathrm{mM}$, $\mathrm{pH}=7), \mathrm{H}_{2} \mathrm{O}_{2}(1 \mathrm{~mL}, 1 \%)$, guaiacol $(1 \mathrm{~mL}, 1 \%)$, and enzyme extracts $(20 \mu \mathrm{L})$. The absorbance of the reaction mixtures was recorded at $470 \mathrm{~nm}$ via spectrophotometer (Biochrom WPA Biowave II UV/Visible), and the increment in absorbance at $470 \mathrm{~nm}$ was followed for $1 \mathrm{~min}$. The activity was stated as mmole activity $\mathrm{mg}^{-1}$ protein.

\section{Measurement of protein}

Protein concentrations were specified based on the Bradford [23] method, by Bovine Serum Albumin (BSA), as standard protein.

\section{2, 2- Di-Phenyl-1-Picryl Hydrazyl (DPPH) scavenging}

The antiradical activity of the methanol extract of samples was evaluated using a spectrophotometer, via Liyana-Pathirana and Shahidi [24] method. A solution of $0.135 \mathrm{mM} \mathrm{DPPH}$ in methanol was made, and then, $1.0 \mathrm{~mL}$ of this solution was blended with $1.0 \mathrm{~mL}$ of the methanol extract of the samples in methanol including $40-270 \mu \mathrm{g}$ of the methanol extract. The reaction mixtures were vortexed completely and placed for $30 \mathrm{~min}$ in the dark at room temperature. The mixtures absorbance was recorded spectrophotometrically at $517 \mathrm{~nm}$. Ascorbic acid was utilized as a reference. The capability to scavenge DPPH radical was computed using the following equation:

$$
\begin{aligned}
& \text { DPPH scavenging assay }(\%) \\
& =\left[\left(\mathrm{Abs}_{\text {control }}-\mathrm{Abs}_{\text {sample }}\right) / \mathrm{Abs}_{\text {control }}\right] \\
& \quad \times 100 .
\end{aligned}
$$

where, $\mathrm{Abs}_{\text {control }}$ is the absorbance of DPPH radi$\mathrm{cal}+$ methanol; and $\mathrm{Abs}_{\text {sample }}$ is the absorbance of DPPH radical+samples methanol extract. The radical scavenger activity was stated as the extent of antioxidants required to reduce the primary DPPH absorbance by $50 \%$ $\left(\mathrm{IC}_{50}\right)$. The $\mathrm{IC}_{50}$ amount for any sample was calculated graphically through plotting the percentage of disappearance of DPPH as a function of the sample concentration.

\section{Phytochemical analysis}

Total Phenolic Content (TPC) of the test samples was assayed using Yu et al. [25] Folin-Ciocalteu method, utilizing gallic acid as the standard. Briefly, double distilled water $(900 \mu \mathrm{L})$ was added to the methanolic solution of test samples $\left(100 \mu \mathrm{L}, 100 \mu \mathrm{g} \mathrm{mL}{ }^{-1}\right)$. Then, Folin-Ciocalteu reagent $(500 \mu \mathrm{L})$ was added, followed by the addition of sodium carbonate $(1.5 \mathrm{~mL}, 20 \%)$. The volume of 
the mixture was reached to $10 \mathrm{~mL}$ by the distilled water. The mixture was afterward incubated at room temperature for $2 \mathrm{~h}$. After that, the absorbance was assayed via spectrophotometer (Biochrom WPA Biowave II UV/ Visible) at $725 \mathrm{~nm}$. The same method was used for the standard solutions of gallic acid. Based on the evaluated absorbance, the concentration of phenolic content was determined from the calibration line. Finally, the total phenolic content of methanol extracts was stated as $\mathrm{mg}$ Gallic Acid Equivalents (GAE) $\mathrm{g}^{-1}$ dry matter.

In order to determine the flavonoid content, the colorimetric aluminum chloride method was utilized [26]. Each sample in methanol $\left(0.5 \mathrm{~mL}, 1: 10 \mathrm{~g} \mathrm{~mL}^{-1}\right)$ was blended with methanol $(1.5 \mathrm{~mL})$, potassium acetate $(0.1 \mathrm{~mL}, 1 \mathrm{M})$, aluminum chloride $(0.1 \mathrm{~mL}, 10 \%)$, and the distilled water $(2.8 \mathrm{~mL})$. Then, the extracts were placed at room temperature for $30 \mathrm{~min}$. Afterwards, the absorbance of the reactions was recorded using spectrophotometer (Biochrom WPA Biowave II UV/Visible) at $415 \mathrm{~nm}$. The calibration curve was plotted through making quercetin solutions (12.5 to $100 \mu \mathrm{g} \mathrm{mL}^{-1}$ ) in methanol. Finally, the total flavonoid content was stated as $\mathrm{mg}$ of quercetin equivalents $\mathrm{g}^{-1}$ of dry sample.

\section{Antibacterial screening}

Microorganisms Staphylococcus aureus PTCC 1431, Bacillus subtilis PTCC 1023, Pseudomonas aeruginosa PTCC 1074, Escherichia coli PTCC 1330, Pseudomonas syringae subsp. Syringae ICMP 5089, Pseudomonas viridiflava ICMP 2848, Rathayibacter toxicus ICMP 9525, and Xanthomonas campestris pv. Campestris ICMP 13 were obtained from the Sari Agricultural and Natural Resources University (SANRU) microbiology laboratory.

The antibacterial effect of the methanol and chloroform extracts of the samples was assessed with the disk diffusion method utilizing Mueller-Hinton agar [17, 33], and investigation of inhibition zones of the extracts. The filter paper discs of $6 \mathrm{~mm}$ diameter (Padtan, Iran) were sterilized then impregnated with $25 \mu \mathrm{L}$ of methanol and chloroform extracts, separately. The sterile impregnated discs were put on the agar surface by the flamed forceps and softly compressed down to ensure perfect contact of the discs with the agar surface. The incubation condition was $37{ }^{\circ} \mathrm{C}$ for quality control strains and $27^{\circ} \mathrm{C}$ for plant bacteria for $24 \mathrm{~h}$. All trials were performed in triplicate and the results were stated as mean $\pm \mathrm{SD}$.

The antibacterial activity was evaluated by determining the Minimum Inhibitory Concentration (MIC), employing broth dilution method [18]. Each strain was tested with an extract serially diluted in Luria broth, to obtain concentrations ranging from 100 to $0.8 \mu \mathrm{g} \mathrm{mL}^{-1}$. The samples were thereafter stirred, inoculated with $50 \mu \mathrm{g} \mathrm{mL}{ }^{-1}$ of physiologic solution containing $5 \times 10^{8}$ microbial cells, and incubated at $37^{\circ} \mathrm{C}$ for quality control strains and $27^{\circ} \mathrm{C}$ for plant bacteria for $24 \mathrm{~h}$. A number of wells were reserved on each plate for sterility control (no inoculum), inoculum viability (no extract added), and the positive control (Gentamicin). The MIC was stated as the lowest concentration of extract that visibly inhibited the growth of bacterial spots. The assays were performed in triplicate.

To determine the Minimum bactericidal Concentration (MBC), $10 \mu \mathrm{L}$ of aliquot broth were taken from each well, and plated in Mueller-Hinton agar for $24 \mathrm{~h}$ at $37^{\circ} \mathrm{C}$ for quality control strains, and $27{ }^{\circ} \mathrm{C}$ for plant bacteria. The MBC represents the concentration required to kill $99.9 \%$ or more of the initial inoculum [18]. The assays were performed in triplicate.

\section{Antifungal effect}

The following microorganisms were utilized: Fusarium oxysporum, Pyricularia oryzae, and Botrytis cinerea.

The antifungal property of the methanol and chloroform extracts was examined with the agar-well diffusion method [16]. Potato Dextrose Agar (PDA) was seeded by tested fungus. Sterile paper discs of $6 \mathrm{~mm}$ diameter (Padtan, Iran) were impregnated by $25 \mu \mathrm{L}$ of the methanol and chloroform extracts of samples, separately. The sterile impregnated discs were put on the level of the seeded agar plate. The incubation conditions utilized were $28{ }^{\circ} \mathrm{C}$ and $70 \%$ RH for 12-14 days for Pyricularia oryzae and 7-9 days for Botrytis cinerea, and Fusarium oxysporum. The antifungal activity was visualized as a zone of inhibition of fungal growth around the paper disc and the results were stated as mean $\pm \mathrm{SD}$ after three repetitions. Pathogen grown on PDA without plant extract was utilized as control.

\section{Statistical analysis}

Methanol and chloroform extracts tested in triplicate for chemical analysis and bioassays. The obtained data were exposed to Analysis of Variance (ANOVA), following a completely randomized design to determine the Least Significant Difference (LSD) at $\mathrm{P}<0.05$ by SPSS statistical software package (SPSS v. 11.5, IBM Corporation, Armonk, NY, USA). All results were stated as mean \pm SD. Independent-sample $\mathrm{t}$-test was used for selected comparisons between samples. Alpha value was set a priori at $\mathrm{P}<0.05$.

\section{Results and discussion}

\section{Essential oils compounds}

As $S$. flavescens and $P$. harmala plants showed the best antimicrobial activities, they were selected for GC/MS 
analysis to identify the effective compounds. The results are shown below, separately.

\section{S. flavescens}

Thirty-three constituents were recognized in the essential oil of S. flavescens aerial parts, representing 93.70\% of the total essential oil. The essential oil combinations are listed in the order of their elution on the HP-5MS column as follows: Decane $(0.44 \%), \mathrm{p}$-Cymene $(0.31 \%)$, $\gamma$-Terpinene $(0.39 \%), \alpha$-Terpinolene $(0.26 \%)$, Terpinen4-ol (0.35\%), 4-isopropyl-2-cyclohexenone (0.46\%), 1,6- cyclodecadiene (4.59\%), Benzaldehyde, 4-(1-methylethyl)- (1.12\%), Thymol (1.70\%), Carvacrol (0.26\%), $\beta$-Damascenone (0.91\%), Caryophyllene (1.09\%), Nerylacetone $\quad(0.44 \%), \quad 2,6,10,14-$ Tetramethylheptadecane (0.49\%), Alloaromadendrene (6.59\%), $\alpha$-curcumene (0.55\%), $\quad \beta$-Ionone $(0.55 \%), \quad 3,5$-Di-tert-butylphenol (0.48\%), Germacrene D (0.35\%), Dodecanoic acid (3.37\%) (+)-spathulenol (15.39\%), Caryophyllene oxide (1.43\%), Ledene (0.67\%), Tetradecanoic acid (1.13\%), 6,10,14-trimethylpentadecan-2-one (5.15\%), Diisobutyl phthalate $(0.65 \%)$, methyl 14-methylpentadecanoate (1.99\%), $n$-Hexadecanoic acid (8.86\%), Butyl 2-ethyl hexyl phthalate (1.20\%), Squalene (8.87\%), Ethyl linoleolate (4.99\%), Neophytadiene (17.61\%), and Linoleic acid (1.06\%).

GC/MS analysis showed that the main components of the essential oil were Neophytadiene (17.61\%), Spathulenol (15.39\%), and Squalene (8.87\%).

\section{P. harmala}

Eighteen components were identified in the essential oil of $P$. harmala fruits representing $91.76 \%$ of the total essential oil. The essential oil compounds are listed in the order of their elution on the HP-5MS column as follows: Decane $(1.05 \%), \mathrm{m}$-Cymene $(0.78 \%), \gamma$-Terpinene (0.74\%), 4-carvomenthenol (1.52\%), 4-isopropyl-2-cyclohexenone $(0.81 \%)$, Cuminaldehyde $(2.58 \%)$, Thymol $(2.46 \%), \beta$-caryophyllene (1.44\%), 6,10-dimethyl-5,9-undecadiene-2-one $(0.88 \%)$, Alloaromadendrene $(5.00 \%)$ (-)-Spathulenol (37.83\%) (+)-Aromadendrene (1.07\%), $\beta$-oplopenone (0.39\%), Methyl palmitate (1.14\%), $n$-Hexadecanoic acid (13.21\%), Methyl linoleate (1.04\%), Linoleic acid (11.08\%), and Elaidic acid (8.72\%).

GC/MS analysis showed that the main components of the essential oil were Spathulenol (37.83\%), $n$-Hexadecanoic acid (13.21\%), and Linoleic acid (11.08\%).

\section{Protein content and enzymes activity}

Plants have evolved antioxidant pathways that are usually sufficient to protect them from oxidative injury during periods of natural growth and moderate stress. Both enzymatic and non-enzymatic systems protected tissue from the activated oxygen species, produced as the result of external environmental stresses, such as dryness, chilling and air pollution. Certain enzymatic antioxidant defense systems contain Super Oxide Dismutase (SOD), Catalase (CAT), and Guaiacol Peroxidase (GPX) [27]. In this research, the activity of 2 enzymes (CAT and GPX) was evaluated. Moreover, protein content was measured by bovine serum albumin as a standard. The results are exhibited in Fig. 1. As shown, the maximum and the minimum activities of catalase were found in J. conglomeratus and S. flavescens plants, respectively. Besides, guaiacol peroxidase activity assay indicated that $J$. conglomeratus plant had the highest activity. Furthermore, the minimum guaiacol peroxidase activity was related to $R$. repens plant. Moreover, the maximum and the minimum protein contents were observed in M. azedarach fruit and J. conglomeratus plant, respectively.

\section{DPPH radical scavenging effect}

The effect of antioxidants on DPPH. was assumed to be because of their hydrogen donating capability [28]. Table 1 shows the DPPH radical scavenging effect of the tested plants. As presented, the highest free radical scavenging capacity of the plants was determined in $P$. harmala extract with an $\mathrm{IC}_{50}$ value of $0.46 \pm 0.12 \mu \mathrm{g} \mathrm{mL}^{-1}$.

\section{Total phenol and flavonoid content of the extracts}

Plants have unlimited capability to produce aromatic secondary metabolites, which most of them are phenols or their oxygen-substituted derivatives. Key subclasses in this set of compounds contain phenols, phenolic acids, quinones, flavones, flavonoids, flavonols, tannins, and coumarins. These collections of compounds indicate

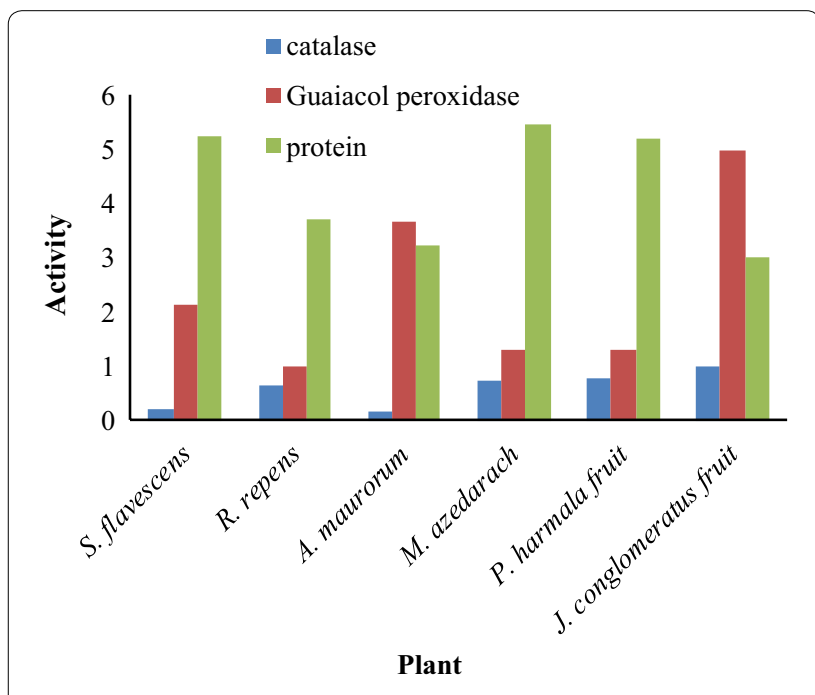

Fig. 1 Enzymes activity and protein content 
antimicrobial activity and apply as plant defense mechanisms versus pathogenic microorganisms. Phenolic toxicity to microorganisms is because of the number of hydroxyl groups and site(s) existing in the phenolic compounds. Phenolic compounds cause cell membrane disruption, increase of ion permeability and leakage of vital intracellular constituents or impairment of bacterial enzyme systems in pathogenic microorganisms [34, 35].

It has been recognized that the antioxidant effect of the flavonoids and their effectiveness on human health and nutrition are considerable. Chelating or scavenging procedures are the action mechanism of flavonoids [29]. The evaluation of total flavonoid content was based on the determining the absorbance amount of tested plant solutions reacting with aluminum chloride reagent, and comparing with the standard solution of quercetin equivalents. The standard curve of quercetin was performed utilizing quercetin concentration ranging from 12.5 to $100 \mu \mathrm{g} \mathrm{mL} \mathrm{m}^{-1}$. The following equation stated the absorbance of the standard solution of quercetin as a function of concentration:

$$
\mathrm{Y}=0.0056 \mathrm{x}+0.1764, \mathrm{R}^{2}=0.9878
$$

where, $\mathrm{x}$ is the absorbance and $\mathrm{Y}$ is the quercetin equivalent $\left(\mathrm{mg} \mathrm{g}^{-1}\right)$. The flavonoid content of samples is shown in Table 1 . As shown, the highest phenol content was determined in A. maurorum, P. harmala and S. flavescens extracts with a value of $45.43,39.3$ and $39.07 \mathrm{mg}$ of quercetin equivalents $\mathrm{g}^{-1}$ of dry matter, respectively.

Phenolic compounds gained from plants are a class of secondary metabolites, acting as an antioxidant or free radical terminators. Therefore, it is necessary to evaluate the total content of phenols in the tested plants [30]. The designation of the total phenolic amount was based on the absorbance amount of sample solutions $\left(100 \mu \mathrm{g} \mathrm{mL}^{-1}\right)$ reacting with Folin-Ciocalteu reagent, and comparing with the standard solution of gallic acid equivalents. The standard curve of gallic acid was performed utilizing gallic acid concentration ranging from 12.5 to $100 \mu \mathrm{g} \mathrm{mL}{ }^{-1}$. The following equation stated the absorbance of the gallic acid standard solution as a function of concentration:

$$
\mathrm{Y}=0.0954 \mathrm{x}+0.196, \mathrm{R}^{2}=0.9973
$$

where, $\mathrm{x}$ is the absorbance and $\mathrm{Y}$ is the gallic acid equivalent $\left(\mathrm{mg} \mathrm{g}^{-1}\right)$. The phenol content of the samples is presented in Table 1. As shown, the highest phenol content was determined in $P$. harmala and A. maurorum extracts with a value of $155.29 \pm 0.20$ and $146.71 \pm 0.02 \mathrm{mg}$ Gallic Acid Equivalents (GAE) $\mathrm{g}^{-1}$ dry matters, respectively.

\section{Antibacterial screening}

The antibacterial activity of methanolic and chloroformic extracts including A. maurorum, S. flavescens, $R$. repens, $M$. azedarach, $P$. harmala and $J$. conglomeratus in different concentrations $(0.01,0.03,0.06,0.12,0.25$ and $0.5 \mathrm{ppm}$ ) were tested versus 3 g-positive (B. subtilis, $S$. aureus, $R$. toxicus) and 5 g-negative (P. aeruginosa, $E$. coli, $X$. campestris, $P$. viridiflava, $P$. syringae) bacteria. The results at $0.5 \mathrm{ppm}$ are shown in Figs. 2, 3. In addition, as in other concentrations, similar results were observed, for simplifying the discussion we considered only $0.5 \mathrm{ppm}$ concentration. As shown in Fig. 2, methanolic extracts of $S$. flavescens, $P$. harmala fruit and J. conglomeratus and chloroformic extracts of $P$. harmala fruit, $S$. flavescens, and $P$. harmala showed the maximum antibacterial activity on $P$. aeruginosa, respectively. Furthermore, methanolic extract of $J$. conglomeratus fruits and chloroformic extracts of $M$. azedarach and $J$. conglomeratus fruit had no antibacterial effect on $P$. aeruginosa (Fig. 2a). The methanolic extract of $P$. harmala and chloroformic extracts of $P$. harmala fruit, $R$. repens, and $M$. azedarach had the maximum antibacterial activity against $B$. subtilis, respectively. Besides, chloroformic extract of A. maurorum extract had no antibacterial activity on $B$. subtilis (Fig. 2b). The methanolic extracts of $P$. harmala fruit, $P$. harmala, and J. conglomeratus and chloroformic extracts of $M$. azedarach and $P$. harmala fruit indicated the maximum antibacterial activity on $E$. coli, respectively (Fig. 2c). Moreover, the methanolic extracts of $P$. harmala fruit, the aerial part and chloroformic extracts of $S$. flavescens and P. harmala fruit had the maximum antibacterial activity on $S$. aureus, respectively (Fig. 2d). Moreover, the antibacterial activity of tested plants on plant bacteria strains is shown in Fig. 3. As indicated, methanolic extracts of $P$. harmala fruit and $S$. flavescens and chloroformic extracts of $R$. repens and $M$. azedarach showed the maximum antibacterial activity against $R$. toxicus, respectively (Fig. 3a). Furthermore, methanolic extracts of $R$. repens and $P$. harmala fruit and chloroformic extracts of $P$. harmala fruit, $J$. conglomeratus fruit and, A. maurorum presented the maximum antibacterial activity against $X$. campestris, respectively (Fig. 3b). The methanolic extract of $P$. harmala fruit and chloroformic extracts of $P$. harmala and $J$. conglomeratus displayed the maximum antibacterial activity on $P$. viridiflava (Fig. 3c). Besides, the methanolic extracts of $S$. flavescens, $P$. harmala fruit and R. repens and chloroformic extracts of $R$. repens represented the maximum antibacterial activity on P. syringae, respectively. However, the methanolic extract of $J$. conglomeratus fruit showed no antibacterial activity (Fig. 3d). 


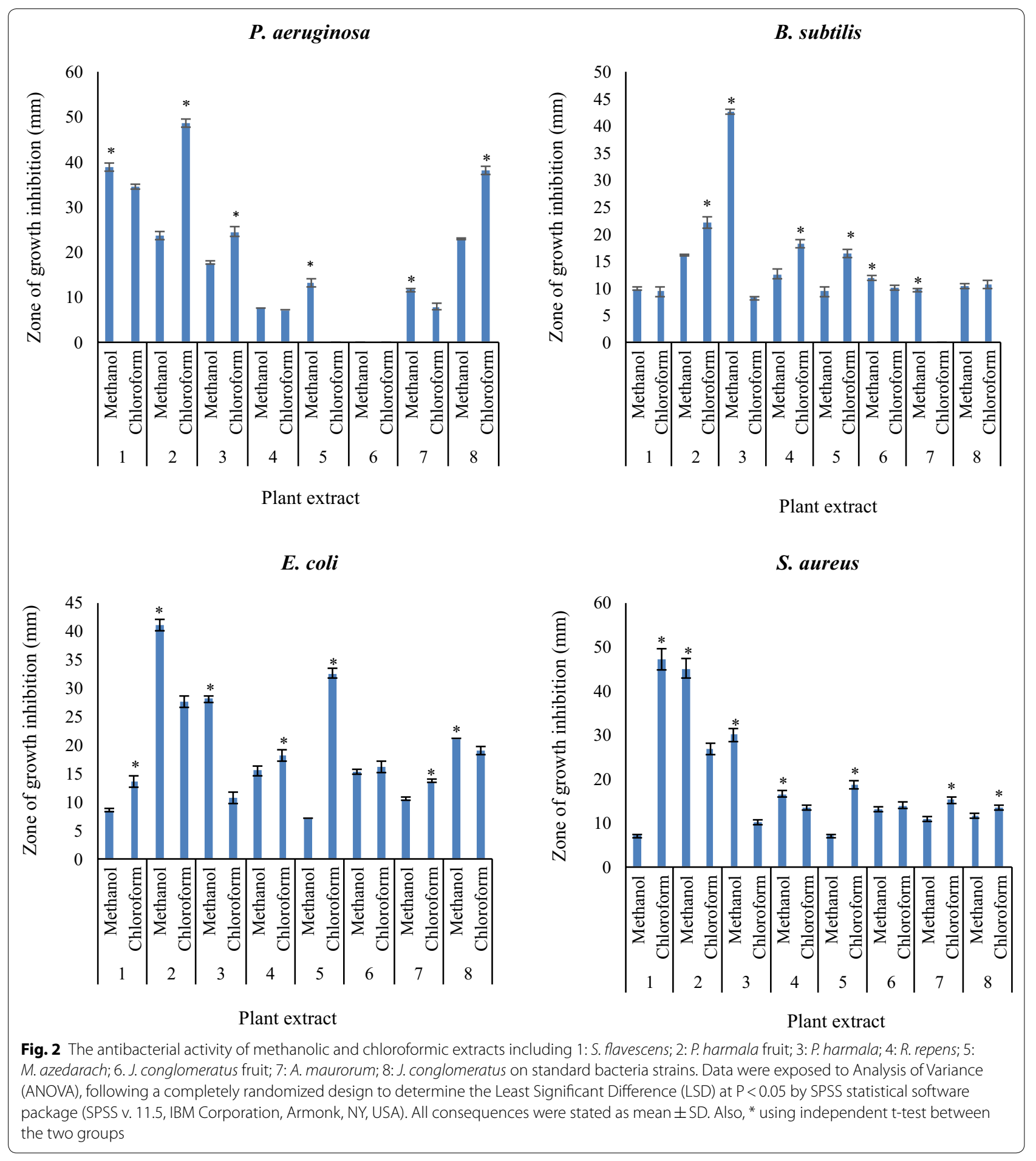

In order to compare the antibacterial activities of methanolic and chloroform extracts, independent-sample t-test was used, indicated with asterisk in Figs. 2, 3. For example, in Fig. 2a, methanolic and chloroform extracts of plants $1,2,3,5,7$ and 8 showed significant differences on Pseudomonas bacteria. In Fig. 2b, methanolic and chloroform extracts of plants 2, 3, 4, 5, 6 and 7 displayed significant differences on B. subtilis. In Fig. 2c, methanolic and chloroform extracts of plants $1,2,3,4$, 5, 7 and 8 exhibited significant differences on E. coli. In 


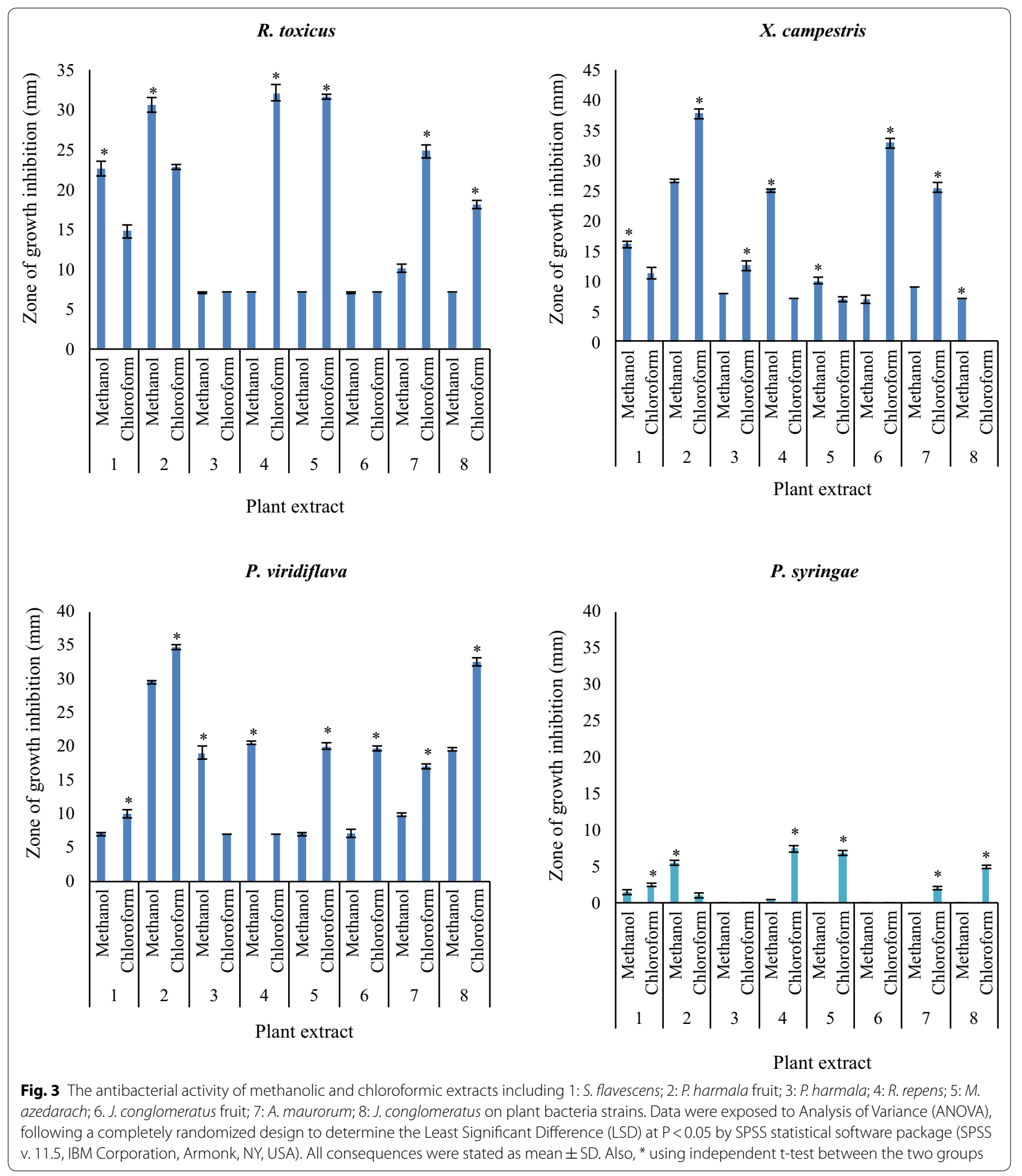

Fig. 2d, methanolic and chloroform extracts of plants $1,2,3,4,5,7$ and 8 exhibited significant differences on $S$. aureus. While in Fig. 3a, methanolic and chloroform extracts of plants 1, 2, 4, 5, 7 and 8 presented significant differences on $R$. toxicu, in Fig. 3b, methanolic and chloroform extracts of plants 1, 2, 3, 4, 5, 6, 7 and 8 presented 
Table 2 The Minimal Inhibitory Concentration (MIC, $\mu \mathrm{g} \mathrm{mL}^{-1}$ ) and the Minimum Microbicidal Concentration (MBC, $\mu \mathrm{g} \mathrm{m}^{-1}$ ) of the methanolic extract of the tested medicinal plants against bacteria

\begin{tabular}{|c|c|c|c|c|c|c|c|}
\hline \multirow[t]{2}{*}{ Strain } & \multicolumn{6}{|l|}{ MIC (MBC) } & \multirow[t]{2}{*}{ Gentamicin } \\
\hline & S. flavescens & R. repens & A. maurorum & M. azedarach & P. harmala fruit & $\begin{array}{l}\text { J. conglomeratus } \\
\text { fruit }\end{array}$ & \\
\hline B. subtilis & $--^{\mathrm{a}}$ & $50(100)$ & - & - & $50(100)$ & $100(-)$ & 6.24 \\
\hline S. aureus & - & $50(100)$ & $100(-)$ & - & $1.56(3.12)$ & $50(100)$ & 3.12 \\
\hline R. toxicus & $25(50)$ & - & - & - & $12.5(25)$ & - & $N S^{b}$ \\
\hline E. coli & - & $50(100)$ & - & - & $1.56(3.12)$ & $50(100)$ & 1.56 \\
\hline P. aeruginosa & $12.5(25)$ & - & $100(-)$ & $50(100)$ & $25(50)$ & - & 12.48 \\
\hline P. syringae & - & $100(-)$ & - & - & $100(-)$ & - & NS \\
\hline P. viridiflava & - & $25(50)$ & - & - & $25(50)$ & - & NS \\
\hline X. campestris & $50(100)$ & $25(50)$ & - & - & $25(50)$ & - & NS \\
\hline
\end{tabular}

${ }^{a}$ No inhibition with the highest concentration in the test conditions

b Not specified

Table 3 The Minimal Inhibitory Concentration (MIC, $\mu \mathrm{g} \mathrm{mL}^{-1}$ ) and the Minimum Microbicidal Concentration (MBC, $\mu \mathrm{g} \mathrm{mL}^{-1}$ ) of the chloroformic extract of the tested medicinal plants against bacteria

\begin{tabular}{|c|c|c|c|c|c|c|c|}
\hline \multirow[t]{2}{*}{ Strain } & \multicolumn{6}{|l|}{$\mathrm{MIC}(\mathrm{MBC})$} & \multirow[t]{2}{*}{ Gentamicin } \\
\hline & S. flavescens & R. repens & A. maurorum & M. azedarach & P. harmala fruit & $\begin{array}{l}\text { J. conglomeratus } \\
\text { fruit }\end{array}$ & \\
\hline B. subtilis & $-^{a}$ & $50(100)$ & - & $50(100)$ & $25(50)$ & - & 6.24 \\
\hline S. aureus & $1.56(3.12)$ & $50(100)$ & $50(100)$ & $50(100)$ & $25(50)$ & $50(100)$ & 3.12 \\
\hline R. toxicus & $50(100)$ & $12.5(25)$ & $25(50)$ & $12.5(25)$ & $25(50)$ & $25(50)$ & $N S^{b}$ \\
\hline E. coli & $100(100)$ & $50(100)$ & $50(100)$ & $12.5(25)$ & $25(50)$ & $50(100)$ & 1.56 \\
\hline P. aeruginosa & $12.5(25)$ & - & - & - & $1.56(3.12)$ & - & 12.48 \\
\hline P. syringae & - & $100(-)$ & - & 100 & - & - & NS \\
\hline P. viridiflava & - & - & $50(100)$ & 25 & $12.5(25)$ & $50(100)$ & NS \\
\hline X.campestris & 100 (100) & - & $25(50)$ & - & $12.5(25)$ & $12.5(25)$ & NS \\
\hline
\end{tabular}

a No inhibition with the highest concentration in the test conditions

b Not specified

significant differences on $X$. campestris. Besides, in Fig. 3c, methanolic and chloroform extracts of plants 1,2, $3,4,5,6,7$ and 8 showed significant differences on $P$. viridiflava, whereas in Fig. 3d, methanolic and chloroform extracts of plants $1,2,3,4,5,6,7$ and 8 showed significant differences on P. syringae.

Furthermore, Tables 2, 3 illustrate the MIC and MBC values of the methanolic and chloroformic extracts of the tested medicinal plants against bacteria, respectively. The methanolic extract of $P$. harmala fruits showed the maximum activity against $S$. aureus and $E$. coli with $\mathrm{MIC}=1.56 \mu \mathrm{g} \mathrm{mL}{ }^{-1}$. In addition, chloroformic extracts of $S$. flavescens and $P$. harmala fruit indicated maximum activity against $S$. aureus and $P$. aeruginosa with $\mathrm{MIC}=1.56 \mu \mathrm{g} \mathrm{mL}^{-1}$, respectively.

\section{Antifungal activity}

The antifungal properties of the methanolic and chloroformic extracts were tested using the agar well diffusion method. The results of the experiments showed that none of the tested plants had antifungal activity.

The use of herbal extracts as antioxidant and antimicrobial agents has two separate advantages: the natural origin and the related low risk. This means that they cause fewer side effects for people and the environment [31]. Based on the results, methanolic and chloroformic extracts of $P$. harmala fruit showed the maximum antibacterial activity against most of the tested bacteria pathogens, attributable to higher content of phenolic and flavonoid compounds. In addition, our findings were in agreement with those of Hayet et al. [9] and Guergour 
et al. [32]. Methanolic and chloroformic extracts of $S$. flavescens indicated the maximum antibacterial activity against $P$. aeruginosa and $S$. aureus, respectively. Our findings were in according with Han and Guo [10] and Yang et al. [31]. Chloroformic extract of $M$. azedarach represented the maximum antibacterial activity on $E$. coli, in accordance with Sen and Batra [11]. methanolic and chloroformic extracts of A. maurorum indicated antibacterial activity against all tested bacteria pathogens, in agreement with the study of Ahmad et al. [12].

\section{Conclusion}

In this work, the antimicrobial and antioxidant activities of extracts of some plants used in Iranian folklore medicine were reported. Based on the results, methanolic and chloroformic extracts of $P$. harmala fruit showed the maximum antibacterial activity against most of the tested bacteria pathogens, attributable to higher content of phenolic and flavonoid compounds. According to the obtained results, a high resolution GC/MS method reported for the evaluation of the constituents of $P$. harmala and S. flavescens plants, while in both plants, Spathulenol was the main component of the essential oil. Furthermore, in this study, the antibacterial and antifungal activities of medicinal plants extracts on plant bacteria and fungi strains were evaluated for the first time. Furthermore, antioxidant assays including measurement of catalase, guaiacol peroxidase and protein were reported for the first time in this study.

In conclusion, the results confirmed the traditional use of the herb against antimicrobial diseases. These plants could act as a potential antimicrobial agent; however, further studies are required for them to be safely used in the control of disease and pests.

\section{Acknowledgements}

The financial support of this work from Genetics and Agricultural Biotechnology Institute of Tabarestan (GABIT) is gratefully acknowledged.

\section{Authors' contributions \\ GN and SG designed the experiment and revised the manuscript with co-author. ZH conducted the experimental work. GN, SGh and ZH analyzed the data and wrote the manuscript. All authors read and approved the final manuscript.}

\section{Funding}

The research was funded by Genetics and Agricultural Biotechnology Institute of Tabarestan (GABIT), Sari Agricultural Sciences and Natural Resources University, Iran.

\section{Availability of data and materials}

All data and materials are all provided.

\section{Competing interest}

The authors have no conflicts of interest.

\section{Author details}

${ }^{1}$ Department of Plant Breeding, Sari Agricultural Sciences and Natural Resources University, Sari, Iran. ${ }^{2}$ Sari University of Agricultural Sciences and Natural Resources, Genetics and Agricultural Biotechnology Institute of Tabarestan (GABIT), Sari, Iran.

Received: 9 October 2019 Accepted: 9 April 2020

Published online: 25 April 2020

\section{References}

1. Chouhan S, Sharma K, Guleria S (2017) Antimicrobial activity of some essential oils - present status and future perspectives. Medicines 4(3):58

2. Kamonwannasit S, Nantapong N, Kumkrai P, Luecha P, Kupittayanant S, Chudapongse N (2013) Antibacterial activity of Aquilaria crassna leaf extract against Staphylococcus epidermidis by disruption of cell wall. Ann Clin Microbiol Antimicrobials 12(1):20

3. Dash BK, Sen MK, Alam K, Hossain K, Islam R, Banu NA, Rahman S, Jamal AM (2013) Antibacterial activity of Nymphaea nouchali (Burm. f) flower. Ann Clin Microbiol Antimicrobials 12(1):27

4. Adamu M, Naidoo V, Eloff JN (2014) The antibacterial activity, antioxidant activity and selectivity index of leaf extracts of thirteen South African tree species used in ethnoveterinary medicine to treat helminth infections. BMC Vet Res 10(1):52

5. de Mélo Silva IS, da Silva ALL, dos Santos RFEP, de Souza RR, Barbosa AM, Santos KS, Amorim MR, da Trindade LS, Krause LC, Campesatto EA: Evaluation of antibacterial and toxicity activity in vitro of extracts from Tournefortia bicolor SW (Boraginaceae). In: BMC proceedings: 2014. BioMed Central: p. 31

6. de Paula Bicudo B, Rodrigues AB, Mendonça MM, Borges RR, de Almeida $A A$, de Oliveira KMP: Evaluation of antibacterial and antifungal activity of ethanolic extract of Cochlospermum regium (Cochlospermaceae) leaf, a medicinal plant from the Cerrado of Brazil. In: BMC proceedings: 2014. BioMed Central: p. 72

7. Srinivasan D, Nathan S, Suresh T, Perumalsamy PL (2001) Antimicrobial activity of certain Indian medicinal plants used in folkloric medicine. J Ethnopharmacol 74(3):217-220

8. Nagata H, Inagaki Y, Yamamoto Y, Maeda K, Kataoka K, Osawa K, Shizukuishi S (2006) Inhibitory effects of macrocarpals on the biological activity of Porphyromonas gingivalis and other periodontopathic bacteria. Oral Microbiol Immunol 21(3):159-163

9. Hayet E, Maha M, Mata M, Mighri Z, Laurent G, Mahjoub A (2010) Biological activities of Peganum harmala leaves. Afr J Biotech 9(48):8199-8205

10. Han C, Guo J (2012) Antibacterial and anti-inflammatory activity of traditional Chinese herb pairs, Angelica sinensis and Sophora flavescens. Inflammation 35(3):913-919

11. Sen A, Batra A (2012) Evaluation of antimicrobial activity of different solvent extracts of medicinal plant: Melia azedarach L. Int J Curr Pharm Res 4(2):67-73

12. Ahmad N, Shinwari ZK, Hussain J, Perveen R (2015) Phytochemicals, antibacterial and antioxidative investigations of Alhagi maurorum medik. Pak J Bot 47(1):121-124

13. Borra SK, Gurumurthy P, Mahendra J (2013) Antioxidant and free radical scavenging activity of curcumin determined by using different in vitro and ex vivo models. J Med Plants Res 7(36):2680-2690

14. Kumar M, Chandel M, Kumar S, Kaur S (2012) Studies on the antioxidant/ genoprotective activity of extracts of Koelreuteria paniculata laxm. Am J Biomed Sci 1:177-189

15. Nesrin H, Tolan V (2010) Chemical composition, antimicrobial and antioxidant activities of hyssop (Hyssopus officinalis L.) essential oil. Notulae Botanicae Horti Agrobotanici Cluj-Napoca 38(3):99-103

16. Ghahari S, Alinezhad H, Nematzadeh GA, Ghahari S (2015) Phytochemical screening and antimicrobial activities of the constituents isolated from Koelreuteria paniculata leaves. Nat Prod Res 29(19):1865-1869

17. Ghahari S, Alinezhad H, Nematzadeh GA, Tajbakhsh M, Baharfar R (2017) Chemical composition, antioxidant and biological activities of the essential oil and extract of the seeds of glycine max (soybean) from North Iran. Curr Microbiol 74(4):522-531

18. Ghahari S, Alinezhad H, Nematzadeh GA, Tajbakhsh M, Baharfar R (2017) Biochemical composition, Antioxidant and biological activities of the essential oil and fruit extract of Xanthium strumarium Linn. From Northern Iran. J Agric Sci Technol 19:1603-1616 
19. Ghahari S, Alinezhad H, Nematzadeh GA, Tajbakhsh M, Baharfar R (2018) Phytochemical, Antioxidant and Biological Activities of the essential oil of Astragalus alopecurus Pall. Fruits from Northern Iran. J Essent Oil Bear Plants 21(1):103-115

20. Gapińska M, Skłodowska M, Gabara B (2008) Effect of short-and longterm salinity on the activities of antioxidative enzymes and lipid peroxidation in tomato roots. Acta Physiol Plant 30(1):11-18

21. Chance B, Maehly A (1955) [136] Assay of catalases and peroxidases. Methods Enzymol 2:764-775

22. Upadhyaya A, Sankhla D, Davis TD, Sankhla N, Smith B (1985) Effect of paclobutrazol on the activities of some enzymes of activated oxygen metabolism and lipid peroxidation in senescing soybean leaves. J Plant Physiol 121(5):453-461

23. Bradford MM (1976) A rapid and sensitive method for the quantitation of microgram quantities of protein utilizing the principle of protein-dye binding. Anal Biochem 72(1-2):248-254

24. Liyana-Pathirana CM, Shahidi F (2005) Antioxidant activity of commercial soft and hard wheat (Triticum aestivum L.) as affected by gastric $\mathrm{pH}$ conditions. J Agri Food Chem 53(7):2433-2440

25. Yu L, Haley S, Perret J, Harris M, Wilson J, Qian M (2002) Free radical scavenging properties of wheat extracts. J Agri Food Chem 50(6):1619-1624

26. Chang C-C, Yang M-H, Wen H-M, Chern J-C: Estimation of total flavonoid content in propolis by two complementary colorimetric methods. J Food Drug Anal. 2002, 10(3)

27. Kang HM, Saltveit ME (2001) Activity of enzymatic antioxidant defense systems in chilled and heat shocked cucumber seedling radicles. Physiol Plant 113(4):548-556

28. Brighente I, Dias M, Verdi L, Pizzolatti M (2007) Antioxidant activity and total phenolic content of some Brazilian species. Pharm Biol 45(2):156-161
29. Pourmorad F, Hosseinimehr S, Shahabimajd N. Antioxidant activity, phenol and flavonoid contents of some selected Iranian medicinal plants. Afr J Biotechnol. 2006, 5(11)

30. Kumar M, Chandel M, Kumar S, Kaur S (2011) Protective effects of Koelreuteria paniculata Laxm. on oxidative stress and hydrogen peroxideinduced DNA damage. Phytopharmacology 1(5):177-189

31. Yang J-F, Yang C-H, Wu C-C, Chuang L-Y (2015) Antioxidant and antimicrobial activities of the extracts from Sophora flavescens. J Pharmacog Phytochem 3(6):26-31

32. Guergour H, Allouni RR, Bouzidi A (2018) A: phytochemical screening, antioxidant activity of the various extracts from Peganum harmala (Zygophyllaceae). Der Pharma Chemica 10(3):146-150

33. Jahantighi A, Kiani G, Moghaddam TT, Ghahari S. In vitro antibacterial activity of selected medicinal plants traditionally used in Iran against plant and human pathogenic bacteria. 2016:4221. http://jjbs.hu.edu.jo.

34. Gurjar MS, Ali S, Akhtar M, Singh KS (2012) Efficacy of plant extracts in plant disease management. Agri Sci 3(3):425

35. Sandri I, Zacaria J, Fracaro F, Delamare A, Echeverrigaray S (2007) Antimicrobial activity of the essential oils of Brazilian species of the genus Cunila against foodborne pathogens and spoiling bacteria. Food Chem 103(3):823-828

\section{Publisher's Note}

Springer Nature remains neutral with regard to jurisdictional claims in published maps and institutional affiliations.
Ready to submit your research? Choose BMC and benefit from:

- fast, convenient online submission

- thorough peer review by experienced researchers in your field

- rapid publication on acceptance

- support for research data, including large and complex data types

- gold Open Access which fosters wider collaboration and increased citations

- maximum visibility for your research: over 100M website views per year

At BMC, research is always in progress.

Learn more biomedcentral.com/submissions 